the large endowment the founders hoped for in the early days, when they planned a different sort of institute with a large permanent faculty. "If I were wealthy, I'd want to give my money to something new, challenging and exciting - something like the Santa Fe Institute." But he thinks things are improving on the money-raising front: "Ellen is a fireball."

John Casti, a visiting member of faculty from the Technical University of Vienna in Austria and editor of Complexity, the house journal, says that although opinion is divided over the question of resident faculty, there is no fierce in-fighting.

Casti looks at the Institute for Advanced Study in Princeton, New Jersey — which has hired permanent faculty of exceptional ability but has arguably failed in crossdisciplinary research - as an example of how "empire-building" sets in when positions are assured for life.

The new management team at Santa Fe thinks the institute needs to shed its reputation for arrogance and reach out to a wider scientific community. But, as Casti points out, the arrogance may be implicit in Santa Fe's novel approach to scientific enquiry. "This institute has gotten a lot of heat from people who say that what we're doing is not really science," he says. "The Santa Fe Institute is pushing a brand of intellectual medicine that is by no means universally accepted. People here have to be real risktakers - people with monumental selfconfidence who don't care what anyone else says."

ColinMacilwain

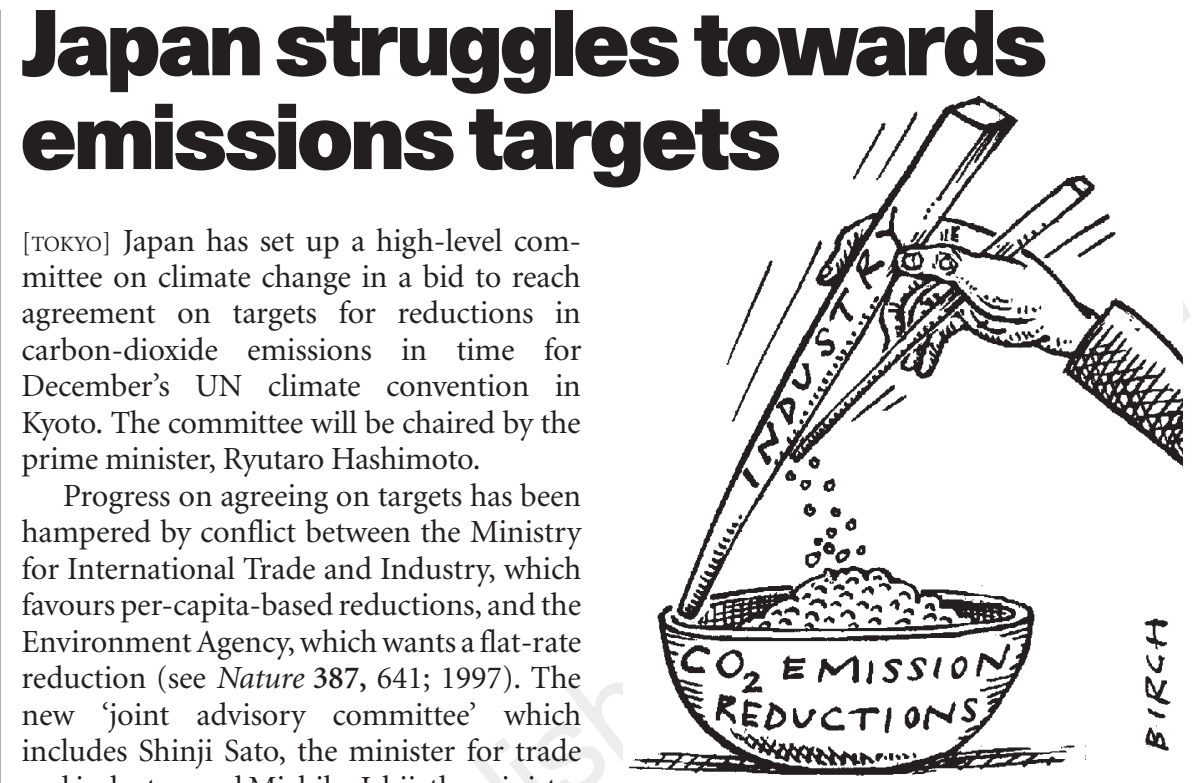
and industry, and Michiko Ishii, the minister of state of the Environmental Agency - is intended to get the two sides talking.

The committee is expected to recommend emission-reduction targets in time for the final preparatory meeting of the Kyoto conference in Bonn in October. According to press reports, Michiko Ishii announced last week that a "Japanese proposal for reduction targets should be above five per cent".

Environmental and consumer organizations complain, however, that industry interests are overrepresented on the committee. Citizen groups and nongovernmental organizations should also have been included, argues Setsuko Sumino of People's Forum 2001, a Japanese association of citizen groups. Critics are also unhappy that the committee's deliberations have not been made public.

In a related development, Diet members from the ruling coalition parties - the Liberal Democratic Party (LDP), Sakigake, and the Socialist Party — have also set up a discussion forum, chaired by the LDP politician Kazuo Aichi. The forum is to draft a consensus proposal on emission-reduction targets. Aichi is reported to have said that targets of up to ten per cent might be envisaged.

RobertTriendl

\title{
'Slick' new company eyes medical diagnostics market
}

[SAN FRANCISCO] Incyte Pharmaceuticals, Inc. and SmithKline Beecham (SKB) are to create a joint venture company called diaDexus to discover and commercialize molecular diagnostic products in a deal which brings together some of the newest technology in the area.

diaDexus will be based in Santa Clara, California, and will be owned equally by both parent companies. It will use bioinformatics and genomics initially to develop tests for disease detection, with particular emphasis on infectious diseases and oncology. The company also plans to create pharmacogenomic tests to optimize clinical drug testing and disease treatment according to the genetic differences between people.

Rachel Leheny, biotechnology industry analyst for the investment company Hambrecht \& Quist, Inc., calls the arrangement "slick". She says both companies bring significant technology and financial resources to the venture, and predicts that this should help to make diaDexus one of the three companies likely to dominate genomics-based diagnostics in the future. The other candidates, she predicts, are the California-based company Affymetrix, which is developing sophisticated DNA-chip technology, and the collaboration announced in July between Abbott Laboratories and the French company Genset to develop diagnostics for customizing pharmaceuticals for patient use.

Leheny says these companies were targeting a very lucrative segment of the future pharmaceutical business. Disease detection is their near-term goal, with pharmocogenomics "the holy grail", she said, adding that the deal underlines the sophistication of Incyte's genomics capabilities. "I think SmithKline saw that if they really needed to be competitive, they needed to get access to the best database," she said.

Incyte, which is based in Palo Alto, California, will provide diaDexus with nonexclusive access to its extensive human and microbial genomics databases. The new company will also have access to information from SKB's partners in genomics, including the Rockville,
Maryland-based company Human Genome Sciences, and to diagnostic data originating from SKB's own therapeutic research. Incyte and SKB said they would contribute a combined total of $\$ 25$ million to start the new company, which will have around 30 staff.

diaDexus plans initially to license proprietary diagnostic markers to diagnostic-kit manufacturers. The new company also will start business with five tests in late-stage-disease validation, including three for cancer and one for bone disease. Company officials said they hoped to introduce their first "homebrew" service laboratory test within two years, with diagnostic kits approved by the Food and Drug Administration ready within six years.

Dr George Poste, chief science and technology officer of SKB - which has its US headquarters in Philadelphia — will be chairman of the new company. John Burczak, director of research in molecular diagnostics at SKB, will become its research and development director. A chief executive will be hired early next year.

Sally Lehrman 